Border Experiences: Communication and Languages 


\section{Digital media practices as digital border experiences among French cross-border commuters in Luxembourg}

\section{Corinne Martin}

\section{Abstract}

The purpose of this chapter is to analyze the impact of a digital border on the digital media practices of French cross-border commuters in Luxembourg, and how this contributes to the construction of their border experiences. An outline is given of the typology of media practices, and put into perspective with the social representations of the border, the Greater Region, and the position of the cross-border commuters in the social, professional, and cultural space. The methodology is qualitative: semi-directive interviews ( $\mathrm{N}=20,10$ women, 10 men) addressed all the media practices of the respondents (traditional media, digital media, and social networks via smartphones/computers/tablets) and their real-life experiences as cross-border commuters.

\section{Keywords}

Border, digital border, cross-border commuters, digital media, digital practices

\section{Introduction: the circulation of news in the media in the Greater Region}

Our study aims to highlight the impacts of the digital border on the digital media practices of French cross-border commuters working in the Grand Duchy of Luxembourg. Firstly, our project is mainly within the current of studies on domestication, the sociology of uses, and media sociology in analyzing digital media practices (Silverstone/Haddon 1996; Jouët 2000; Jouët/Rieffel 2013). Secondly, we developed our research in the context of the Infotransfront project ${ }^{1}$ (2010-2014) initiated at the CREM (Centre de Recherche sur les Médiations) and supported by the MSH (Maison des Sciences de l'Homme) at the University of Lorraine, in partnership with the Franco-

1 Project headed by Vincent Goulet. 
German University, the University of the Saarland, CIERA (Centre Interdisciplinaire d'Etudes et de Recherches sur l'Allemagne), and LISER (Luxembourg Institute of Socio-Economic Research, formerly CEPS-INSTEAD). The aim of the Infotransfront project was to analyze the circulation of media information in the Greater Region (Goulet/Vatter 2015). More particularly, it involved gaining an understanding of how, in the context of the construction of a cross-border area (Hamman 2005; Goulet/Vatter 2013; Koukoutsaki-Monnier 2014; Hamez 2015; Durand 2015; Amilhat Szary 2016), a regional cross-border media field (Goulet/Vatter 2015) could emerge-or not.

In this context, the aim of our own study was to gain an understanding of practices of consulting media news on a smartphone (and/or tablet)—in other words, digital and mobile media practices-among French cross-border commuters in the Grand Duchy of Luxembourg, compared with the more traditional practices of consulting the media (printed press, radio, television), in order to measure all the specific and complementary features of this method of consulting news reports in the digital age (Granjon/Le Foulgoc 2010; Granjon/Le Foulgoc 2011; Jouët/Rieffel 2013). Thus, one of the first questions we sought to answer was: does being a cross-border commuter and traveling every day encourage-or discourage - the consultation of news on a smartphone? And if it did encourage consultation, what type of news was consulted? More particularly, what place did local news-i.e. that relating to the Greater Region-occupy ${ }^{2}$ ? In other words, are the residents of one country interested in what happens on the other side of the border? What hybridization takes place between the digital media and the traditional media to compensate for the reported absence of cross-border information in the latter type?

The empirical survey carried out in $2012-2013^{3}$ (cf. infra) very quickly revealed the existence of what we have qualified as a real digital border: in the field of mobile communications, roaming charges between the various countries of Europe were introduced as soon as mobile phones emerged (in the mid-1990s), resulting in not inconsiderable charges for mobile communications billed to cross-border commuters. Therefore, cross-border commuters were compelled to disconnect ${ }^{4}$ (cut off from their French net-

2 For a detailed analysis of the characteristics of the Greater Region, cf. Belkacem/ Pigeron 2012.

3 The survey was carried out well before the European Union put an end to roaming charges in June 2017.

4 As opposed to the claim of the right to disconnect, analyzed by the sociologist Francis Jauréguiberry (2014). 
work) exactly at the moment they crossed the border to enter the area of the Grand Duchy. How was their border experience constructed, being associated with that cut-off every morning to go to work? How did they manage to maintain communication with their relatives who remained in France during the whole working day? We propose the hypothesis that this economico-technical apparatus - the roaming charges-shaped (Cardon 2010) their border experiences and made their digital practices specific. Is it possible to analyze this digital border in the context of the phenomena of re-bordering?

We were able in this way to highlight three major repertoires of usage covering the routines and practices of consulting news. These repertoires of usage have been linked to their sociability and cultural practices (Donnat 2009), and their everyday experiences-including their border experiences - in the tradition of studies on the domestication and sociology of uses (Jouët 2001; Jouët/Rieffel 2013). It is these three repertoires of usage that will be presented.

The methodology is qualitative, inspired by the tradition of the non-directive interview that gives prominence to the participant's viewpoint (Blanchet, 1985; Blanchet/Gotman, 1992). Twenty non-directive interviews were carried out (with 10 men and 10 women, aged between 23 and 48, interview lasting one to two hours), all transcribed in full; they constitute our corpus. We are able to state that this sample is sufficiently diversified, particularly in terms of the socio-professional and cultural origin of the respondents. Similarly, our work was guided by the comprehensive interview method developed by Jean-Claude Kaufmann (1996). This is justified by grounded theory: instead of drawing up prior hypotheses, we attempted to construct hypotheses on the basis of the information gathered in the field, and our initial analysis after the interviews had been held led us to posit the hypothesis of a real digital border. This is what we shall cover in this paper's first section, before presenting the three repertoires of usage.

\section{A digital border that promotes re-bordering phenomena}

While it was easy to understand a priori that mobile phone communications between the countries of the European Union were restricted by 
their not inconsiderable $\operatorname{cost}^{5}$, the field survey revealed just what a massive impact this phenomenon had on the cross-border commuters we met and on their everyday mobile communications, from the introduction of the mobile phone (mid-1990s) to June 2017 (the end of roaming charges; it should be recalled that the field survey was carried out in 2012-2013, see above). Everyone mentioned the surprising phenomenon that occurred at a specific place, very close to the place they crossed (by car or in a train) the geographical border between France and the Grand Duchy: conversations were interrupted, pages stopped downloading, and there was no signal. Mobile phones were put away in pockets by all those users who only had subscriptions to a French network. We have qualified this cut-off point as a real digital border, in as much as it was a reminder of the demarcation line of the borders which are no longer materially visible in this cross-border area. This digital border even affected cross-border commuters with high purchasing power. Nearly all deplored or criticized this state of affairs; it is interesting to see the various impacts this technico-economic apparatus had on these cross-border commuters and their use of mobile devices for more than twenty years. Most of the respondents had in fact learned to filter incoming calls, only answering occasionally, assessing the calls according to the identity of the caller and the degree of urgency, and as a result they postponed looking at their mobile communications with their acquaintances until they returned to France at the end of the working day. It should also be said that their contacts had also evidently learned to avoid calling during the day (except in an emergency). It is therefore interesting to note that there was an impact not only on practices but also on the social imaginary associated with the invention of the mobile phone (ubiquity, the ability to call from anywhere at any time), which had in fact completely disappeared for many cross-border commuters. On the other hand, a number of respondents in our sample-those whose job required management of client relations (mainly in the liberal professions)-found themselves obliged to equip themselves with a second phone (or a second SIM card, for use in a special dual-SIM phone) in order to have access to the Grand Duchy's network. This was the case for Angélique (self-employed in the complementary medicine sector, 37 years old), a professional coach in contact with her clients for appointments, who halved her phone bill by acquiring a second phone; she was now paying 250 euros per

5 The matter of the cost of using mobile phones before the invention of plans including unlimited communications - and the end of roaming charges-was a fundamental issue. 
month instead of the 500 euros she had been paying previously, when she had a single phone and a lot of out-of-plan communications. Lastly, a very small number of respondents in our sample had opted for a specific plan, such as a plan including one hour of calls to landlines in the Grand Duchy, but they remained very much a minority. To end this section, we should also point out that the large majority of respondents had learned to apply ruses and practices to bypass the apparatus of the digital border, thereby developing new "ways of operating" ("manières de faire" defined by Michel de Certeau (1998)) that may be assimilated to instruction manuals. Thus many of the respondents made use of a number of free apps, both for downloading content (including Instapaper and Flipboard, the latter being included by default on some smartphones) and for free messaging WhatsApp. But there were significant constraints: the user still needed a Wi-Fi connection to be able to use WhatsApp-thereby excluding the possibility of communicating during the commuter journey-and, particularly for Instapaper, the need to anticipate and download while the user was still connected to the network.

This was the case for Charles (a computer specialist, 26 years old), who discovered Instapaper and used it to download and, more particularly, save a few articles to read offline on his smartphone during the journey by train and bus to Luxembourg City. For his IT thesis he was required to carry out an information watch, which made him a "big consumer of information", and he developed a quasi-routine. He made a note of articles of interest (he subscribed to a number of RSS feeds from pre-selected sites) the night before or during the day while working on the computer he was using to prepare his thesis, then synchronized them onto his iPhone and downloaded them in the morning as he stood on the platform waiting for his train, using Instapaper. As Charles pointed out, however, there was one major constraint: "you have to plan ahead".

Another interesting case was that of Anaïs (a management assistant, 25 years old), whose interview revealed nothing short of a re-bordering phenomenon in her management of calls to and from her network of Luxembourgish and Belgian acquaintances and co-workers. Before making any call from her workplace, she would always consider where the other person might be geographically, and the type of mobile phone plan they had (French or Luxembourgish network), and the time of day (still at work or already back home in France or Belgium) - her aim being to make the best use of the cost of her two mobile phones:

I have a Belgian friend [a Belgian cross-border commuter; we used to work together when I had a previous job in the Grand Duchy] so I 
know she'll be in Belgium, so I always use my Luxembourg mobile phone to text her since it's cheaper than using my French mobile phone. I know French people working in the Grand Duchy too, so I have to think about it... for instance, given the time it is now, is he going to be in France [laughter], in which case I'll use my French mobile phone because I've got unlimited text messaging? Or is he in the Grand Duchy at the moment, in which case I'll use my Luxembourg phone? But if I'm in France and using my Luxembourg phone, is that going to be cheaper or more expensive than if I were in the Grand Duchy? Well, it was a real disaster [laughter] [...] well, it was all about making it cheaper but in fact, er well, it was a bit cheaper, but it was more complicated than it was worth, really.

The cognitive cost was indeed far from negligible, and Anais eventually lost her Luxembourg mobile phone. To sum up, the digital practices of the respondents in our sample were all impacted in one way or another by this digital border. We shall now move on to describe and analyze in the next three sections the three repertoires of usage we were able to identify on the basis of the empirical survey.

\section{The "tunnel" effect}

Economists call employees who travel backwards and forwards between the place where they live and the place where they work, and who are a feature of large metropolises, commuters or 'pendular migrants': the imagery is very clear (cf. Foucault's pendulum, 1861). Every morning, they cross a border to get to work, and cross back again in the opposite direction in the evening to go back home. The blogger Sylvie Neidinger ${ }^{6}$ has added a bit of humorous wordplay (in French) to the purely statistical approach by describing in her own way the people she calls "cross-border pendular travelers" ("les pendulaires frontaliers"): the cross-border commuter is compared to "a ping-pong ball that two states send backwards and forwards at fixed times in a faultless mechanical fashion". In the qualitative approach we adopted, the image of a "tunnel effect" stood out quite obviously. We shall deal with this in the next section.

6 Sylvie Neidinger posted a blog about commuters. http://duboutduborddulac.blog.tdg.ch/archive/2011/12/23/les-pendu-laires-2-2.html; Retrieved on April 21, 2018. 


\subsection{The geographical border: a new border between private life and work?}

In this section, we will demonstrate how the geographical boundary becomes a metaphor for the boundary between work and private life on a daily basis and thus contributes to the construction of border experiences.

\subsubsection{Exacerbated pendular migration}

Why have we referred to a tunnel effect? The narratives of many of the cross-border commuters in this group with this experience of pendular migration as they described it evoked the metaphorical image of a tunnel: it is as if they were being teleported through a tunnel to their place of work, either in a train or in a car stuck in a long traffic jam. Florence (a psychologist, 38 years old) gave an excellent description of this image of long rows of workers, which even reminded her of workers leaving the factory in her childhood (her father was such a worker):

So when I think of a cross-border commuter, I see myself in the morning on my way to the station. I park, get out of the car, and there's this mass of people walking in silence towards the station. I say to myself, "Well, it's not a factory, is it?" But sometimes I tell myself that anyone watching us must think we're really..., well, stupid, because it's really... We're all traveling to work half-asleep; yes, that's what it is. It's the train, and the people... Well, that's what I see in the phrase 'crossborder commuter'.

Does the idea of this "mass" of people correspond to a crowd as Gabriel de Tarde means it? (Moscovici 2005). Is it a mass of "stupid" people who have lost their freedom of will and their critical faculties? At any event, they stay grouped together; they are not responsive-in fact, they seem submissive, like automatons, but the scene taking place at six o'clock in the morning makes the experience of these pendular migrants relatively similar to that of the inhabitants of major metropolises, such as Paris or elsewhere.

So why have we mentioned the extreme dimension of this pendular migration? Because it is as if these cross-border commuters were going through a "tunnel"-wearing blinkers that prevented them from seeing what was happening on the spot, in the Grand Duchy. They never stayed on in the evening after work, never came back at the weekend, never pursued any leisure, sport, or cultural activities in the geographical area of the Grand Duchy, and took little or no interest in what was going on locally. Their media practices guided them towards the French/international news 
since, as far as they were concerned, "local news" remained the news of their place of residence or the area in which they lived. Lastly, they developed almost no sociability with people living in the Grand Duchy and they stayed "among themselves" and did not mix, since they were working in companies that mainly recruited cross-border commuters like themselves. And they were quite simply keen to get back home in the evening, since a cross-border commuter's day is long enough as it is, particularly because of the time spent traveling. The interviewer's question: "As a crossborder commuter, do you have any activities in the Grand Duchy apart from your work?" elicited a negative reply from many of the respondents in this group; at best, their reply was "not very often". One aspect involved here was the amount of time "lost" traveling7, time that ceased to be available for leisure activities. As a result, many of the respondents reported a kind of hermetic separation between work and "everything else", i.e. their private lives and leisure activities, the latter being only very rarely carried out in the Grand Duchy. The case of Jean-Pierre (an administrative agent, 46 years old) shed light on this:

No, because afterwards I'm quite happy to... er, once the day's over... I don't stay on [...] I don't stay, no, of course I don't stay [...] so, well, er, I don't know, I'm interested, it's not that I'm not interested [defensively], but I mean, er; I'm glad the day's over so that's it, it's finished, you know? [...] no, no, after the Grand Duchy... I work there, it doesn't go further than that... you know? [laughter] [...] but, since I live near Metz, I don't know, er... I've had enough of being in the same place as I work, and it doesn't go any further than that, I don't do any more afterwards, I don't come back... here... you could say, my working life is here, and everything else is in France.

Jean-Pierre was very clear on this point: he separated his working life from "everything else", meaning his private life, which was almost unlimitednot finite, in any case. In contrast, working time had to be limited, constrained, regulated-“it doesn't go any further than that"-and after work he was "glad the day's over"; the expressions "I've had enough of being in the same place as I work", "I don't stay on", and "I'm not interested" are very clear. As for weekends, he remembered returning to the Grand Duchy on no more than one occasion, bearing in mind that he had been working

7 Some spend between two and three and a half hours in a bus every day; the time spent in a car is equally long (because of the inevitable daily traffic jams on the single motorway into the Grand Duchy). 
in the Grand Duchy for ten years. Many cross-border commuters in this group managed to make a clear dividing line between work and their private lives.

\subsubsection{Reconstructing a border between work and private life}

It did indeed seem that these cross-border commuters managed to gain some kind of secondary advantage (in the psychological sense) from their daily migration: after rationalizing and hence inverting the negative mental charge into a quasi-positive charge, traveling time was used as a real "decompression chamber" after work, and the geographical border was symbolically requalified and mentally reconstructed, becoming a new border dividing work and private life. This is a not inconsiderable advantage, given the problems many employees experience in relation to the increasing porosity of the border between work and the private sphere, as a result of the intensive use made of digital technologies and the new relationship with time and urgency they have promoted in our contemporary societies (Jauréguiberry 2014; Aubert 2010). Angélique (self-employed in the complementary medicine sector, 37 years old) explained very clearly her need to raise a "barrier" after work, which occurred almost magically at the exact moment she crossed the geographical border:

If I stay on in the Grand Duchy, I always have the impression that it's more for the work environment, because there's a different atmosphere and ambiance $[. .$.$] you feel as if you're still in the work sphere$ with its pressures, er... [...] but when you cross the border, I don't know, there's something happens and it's not the same [smile] that [...] you get the feeling: once you cross the border [exhaled breath] that's it, you've left it behind you... you know, I see so many people here who are stressed, who are all sorts of things, so I know I mustn't store it all up; I have to put up a barrier, so it's not, well it's not... you have to deal with it somehow [...] that's it, because you get the impression you're still at work $[\ldots]$ so crossing the border means leaving all that behind $[\ldots]$. That's the feeling I have, I leave, so I get back to France, I [deep exhaled breath] I relax.

It should be noted that Angélique was self-employed in the complementary medicine sector, offering services (not refunded by the official health scheme) in the field of relaxation, fitness, and nutrition. Her clients were therefore highly stressed people, and she consequently "stored up" their stress; she therefore had a strong need to prevent it happening to her-I 
have to put up a barrier" - and it occurred "when you cross the border, I don't know, there's something happens". She put everything behind her, all the negative affective burden, leaving it in the geographical area of the Grand Duchy; it ceased to affect her, the pressure was off: "[deep exhaled breath] I relax". It should also be said that she was not affected by the rushhour traffic jams, not only because she had chosen to live in France close to the border (she had previously lived much further away in the southern part of Lorraine), but above all because she left early in the morning and returned home late in the evening (her timetable was dependent on appointments with clients).

Thus while the cross-border commuters in this group practiced what we have qualified as "tunnel" migration and were in a hurry to get back to their homes in France in the evening after a long day's work (a working week of 40 hours with abundant overtime at every level), what about their media practices? Did they make any attempt to obtain information and keep abreast of news connected with the Grand Duchy? These are the questions we shall deal with in the next section.

\subsection{Media practices focused on France and international affairs, paying relatively little attention to the Grand Duchy}

What all the members of this group had in common was the fact that they had little interest in news in the Grand Duchy, and reading the daily newspaper L'Essentiel - if they actually did-was quite sufficient. It should be noted that L'Essentiel is a free Luxembourg daily newspaper, part of whose audience is made up of cross-border commuters: it addresses the interests and particularities of cross-border commuters and, at the same time, gives a brief overview of local news in the Grand Duchy. In 2011-2012, during our survey, L'Essentiel took part in setting up the democratic debate on the Luxembourg government's plan to abolish family allowances for cross-border workers (Lamour 2015). There were some differences nevertheless, since the media practices of individuals remained considerably diversified (Granjon/Le Foulgoc 2011; Jouët/Rieffel 2013). We therefore felt it pertinent to consider two categories of media practices within this "tunnel effect" group.

Firstly, those cross-border commuters who were not particularly interested in the news in general and/or those whose main sources of information on current affairs were still the traditional media (particularly the evening news on television, watched on returning to France after work, or the radio in the morning, before leaving for work) were not going to be 
particularly interested in the news in the Grand Duchy, the country where they were working. At best they would skim through L'Essentiel, but not systematically. Some of the respondents said they only read it occasionally, while others, including Karine (a director in the complementary medicine sector, 28 years old), hardly ever looked at it: "I don't have to read it; I don't take the time to do it."

Secondly, one set of cross-border commuters in this group was more interested in news, but it should be noted that their practices in terms of consulting news reports had evolved; they made less use of the traditional media supports (the printed press, television news programs, radio) and more of apps on their smartphones, which enabled them to select both the type of media and the topics of interest to them.

The next case was that of Arnaud (a computer specialist, 28 years old), who described his quasi "addiction" to the news, which he needed in order to clear his mind during his lunch break and instead of a cigarette break. Whereas he had always read the paper version of L'Essentiel previously, he had since downloaded the News Republic ${ }^{8}$ app on his smartphone (smartphone provided by his employer in IT maintenance). "I look at my phone while I'm eating". His main centers of interest selected in the app were "world news", "France", and "high-tech", including all the news on video games. He also often listened to the France Info radio station, sometimes even when he was at work. From this, it transpires that he had very little appetite for news about the Greater Region, except perhaps for minor news items, things happening "nearby", news items concerning the Greater Region that he had been quite happy to come across in L'Essentiel. However, he went on to acknowledge quite freely that he had stopped reading that newspaper on a daily basis since he had started reading the news on his smartphone.

Summing up, we have shown how little interest these respondents in the "tunnel effect" group showed in news in the Greater Region. Even in this last case, L'Essentiel was quite sufficient: no other daily Luxembourgish newspaper in French, free or otherwise, was ever consulted, even when they were at home, although they were quite keen on French/world news or news items connected with their personal centers of interest. So why did they not feel the need to go any further? Why did they not seek more

8 News Republic is actually an aggregator for mobile devices, with links to the content of many traditional media outlets (e.g. The Guardian, Huffington Post, 20 Minutes, etc.). 
detailed information about the country in which they were working? We now need to look at their cultural and social practices.

\subsection{Few cultural and social practices carried out in the Grand Duchy}

We have given an ample description of the "tunnel effect" which led these cross-border commuters to want to engage in their leisure and cultural activities near their place of residence, near their places of sociability, and not want to stay on or come back to the geographical area of the Grand Duchy. As we have seen, there were many reasons for this, connected with not only constraints involving trains and buses but also their affective desire to clearly draw a dividing line between their work and their private lives. The case of Jean-Pierre (an administrative agent, 46 years old) may be recalled; he returned to the Grand Duchy for leisure activities just once in ten years of working there, apart from the traditional annual end-of-year meal with his co-workers. It should not be forgotten, however, that in most cases the co-workers of these cross-border commuters were cross-border commuters themselves, and although a certain level of sociability developed because of their work, they were able to meet up outside the work environment at their place of residence. Occasionally, they would go out with co-workers after work (for a drink or a meal, for example) on the spot in the Grand Duchy, but very few cases were reported to us. The only person in the entire sample to have mentioned "evening parties" at the homes of co-workers living in the Grand Duchy was Arnaud, who was also one of the very few to work in an environment with a majority of Luxembourgish co-workers (sub-contracted to a public service).

In conclusion, these cross-border commuters who experienced the "tunnel effect" had reconstructed-in the place of the former geographical border-a sort of new and more symbolic border between work and their private lives, and had every intention of developing their social and cultural lives in the place where they lived. Their media practices were focused on seeking information on French and international news in general, and reading the free daily newspaper L'Essentiel —if they did-was more than sufficient to assuage their meagre appetite for local news connected with the Grand Duchy. The second group from the sample should now be described; we have labelled them "the ambivalents". 


\section{The ambivalents}

This small group contains those cross-border commuters who were active in the liberal professions and residents (former cross-border commuters) who had developed a limited degree of anchorage in the Grand Duchy. This juxtaposition may appear surprising; it nevertheless came about firstly because of their common desire to integrate-more or less intensivelyand, as a result of this desire to integrate, because of the pervasiveness of the many paradoxes scattered throughout most of their utterances, which show how difficult it had become for them to situate themselves, as if they were to some extent torn between the two countries, between rational demands (becoming integrated into a new country) and more affective demands (retiring comfortably into a known environment/world, their country of origin). Although the group was small in number, the issue characterizing them seemed an interesting one to identify. Moreover, the "ambivalence" or the dilemma the migrants experience in their everyday lives is well-known in Migration Studies (Bolzman 2016). To attempt to understand the origin of this ambivalence, we shall explore the media, cultural, and sociability practices of these respondents.

\subsection{A strategic desire for integration but a paradox-filled discourse}

The members of this small group were residents, plus one cross-border commuter active in a liberal profession (a lawyer, who spent much of his time in the Grand Duchy). All shared one essential concern: that of wanting/having to integrate a minima in the Grand Duchy. The case of Jonathan (a lawyer in a private practice, resident, 29 years old) will serve as a paradigmatic example to illustrate this ambivalence. His desire to integrate was extremely strategic: after studying law in Nancy, he completed his qualification as a lawyer in the Grand Duchy, since there were a number of advantages not available to him in France (he received a grant for the six months the training lasted, followed by a paid placement with a firm of lawyers, which is not the usual practice in France). He said he had not been alone in taking this path (some 150 lawyers graduate each year in the Grand Duchy, and there are about 2,000 lawyers in practice throughout the country, which is a very high proportion of lawyers in the population-much higher than in the Nancy metropolitan area, despite its historic Law Faculty). He opened his own office and became a resident, thereby displaying a marked desire to integrate: "I'm completely integrated 
here: I've done it by choice ... [a few minutes later] this is the country that provides me with a living, so I live here."

Jonathan was even considering the possibility of acquiring dual nationality" in two years' time, so that he could have access to "certain professions that are reserved for Luxembourgers" (Pigeron-Piroth 2009) in the legal field, particularly in the public sector. And yet it quickly appeared that his discourse was full of paradoxes, revealing a manifest ambivalence: Jonathan wanted to keep open the possibility of returning to France one day. He was very happy with the idea of dual nationality recently introduced by the Luxembourg government, since he was overcome at the mere thought of losing his French nationality and thus having the status of a "foreigner" if ever he wanted to return to live in France-a door he wanted to keep open. But it quickly appeared that this ambivalence was making it difficult for him to feel settled in the country and his neighborhood (cf. infra), and he went on to describe himself as a "weekend cross-border commuter". The expression is an interesting and very significant one; he was commuting differently, returning to France every weekend. As for the other residents in this small group, the relative ambivalence regarding their integration was in fact correlated to their restricted local social life in the Grand Duchy.

\subsection{In the end, very limited local social life and local anchoring}

It is a fact that the local sociability of the respondents in this group was very limited. They did not attempt-or did not manage-to truly participate in the life of the village or neighborhood where they lived. Jonathan described himself as a "weekend cross-border commuter", meaning that, resident in the Grand Duchy for the previous five years, he spent all week at his place of work in the Grand Duchy, that he participated "very little in local life here" but took advantage of the weekend to go back to France, to meet up with his friends, to go out, saying that he had very few Luxembourgish friends, and just a few Belgian friends.

The case of Christophe (a computer specialist, resident, 39 years old) is equally interesting. He also felt very torn. Although he had raised a family in the Grand Duchy (two young children) with a woman of Polish origin who had been living there for "more than twenty years" and had acquired Luxembourgish nationality, he still expressed deep ambivalence with re-

9 See the Act of 23 October 2008 for dual nationality. 
gard to integration, since he refused to exclude the possibility of returning to live in France: "I'm thinking about... not coming back... in fact, I don't really know... so, er... [...] well I go there nearly every weekend as it is, so, er..."

He had been living in the Grand Duchy for fourteen years and stated clearly that his family and friends had all stayed in northern Lorraine: he still remained very attached to the area, and went to visit them every weekend. But although his children had been born in the Grand Duchy, had always lived there, and had attended a school in the Luxembourg education system (he was proud that they were able to speak the country's three languages, plus Polish with their mother), he was aware of the difficulties the future might bring. His home town in northern Lorraine "isn't home for them" [his children], so he was looking to the future with some anxiety: "And I expect when they're grown up it will be the same [not home for them], so I'm going to be a bit torn between the two..."

What was he to do if on the one hand his children wanted to stay in the Grand Duchy, in the country where they were born and had always lived, and on the other he wanted to go back to Lorraine? It would be a real dilemma. To overcome this, Christophe went on, just seconds later, to manifest a certain degree of denial_-in fact I don't feel torn between the two because there's so little distance"-while at the same time carrying out nothing short of territorial reunification- "personally, I don't see any border between the two, in fact." Thus the Greater Region made it possible for him not to have to make a choice-he could be in both countries at once since they were part of a single territory: the borders had almost ceased to exist-he had just abolished them. The same applied to all those for whom "the Greater Region has a meaning"; it is a very strong meaning, as it brings the economic and affective dimensions together. It seems that the case of these residents, who were formerly cross-border commuters, might raise questions relatively similar to those sociologists used to ask about migrants, or those that psychologists are asking today, with the benefit of hindsight, with regard to the alternating custody of children: how is it possible to live, integrate, put down roots, and construct one's identity in two different geographical places with the idea of alternating and the possibility of returning always at the back of one's mind? Whatever the case, ambivalence and paradox constituted fundamental characteristics of this group, whose integration into the new country was to some extent limited by their still very strong attachment to their country of origin, as if it were impossible to make a definitive choice (Kaufmann/Jemelin 2008). In the following section, we shall analyze the media practices of this 
group, which will reveal their lack of interest in local news with regard to the Grand Duchy.

\subsection{Media practices turned toward France/the world}

It appears that the media practices of this small group were, ultimately, not that different from those of the first group; they were not particularly interested in local news in the Grand Duchy and, if they were, reading L'Essentiel was quite sufficient for them. They did not read any other Luxembourgish newspaper. Thus, in general their media practices remained oriented toward France and international news. There was only one significant difference in the third group (cf. infra).

The case of Philippe (a partner in a firm of lawyers, 43 years old) is interesting: while he was the only person in the entire sample to subscribe to Le Quotidien (a French-language printed daily newspaper in the Editpress/Le Républicain Lorrain joint venture) for professional reasons (he said he needed to take an interest in local news for the sake of his local clients), he admitted that he never actually read it, because he was actually not interested in Luxembourg news.

Otherwise, that interests us as well... not much what happens... so in the Grand Duchy, well... but we need to know for our work [...] you have to take a bit of an interest in the country where you work.

His utterance is full of ambiguity (need to take an interest vs. lack of real/ actual interest), revealing once again the ambivalence of this group. Thus, Philippe preferred to consult the Le Monde app (with alerts), or Google News. Jonathan, who considered himself a "weekend cross-border commuter", said he was only receptive to local news when he returned to the village of his childhood in southern Lorraine, because at least there he knew the names of the surrounding villages, which was not the case in the Grand Duchy, where he was not involved in local life. And Christophe still entered the postcode of the town where he was born in northern Lorraine when he consulted Google News, and did not read any of the Luxembourgish daily newspapers.

To sum up, the media practices of the respondents in this group were, in the end, not so very different from those of the members of the first group. Their sociability and their involvement in local life were also relatively limited, but the essential difference was that their desire to integrate into the Grand Duchy was particularly evident in their discourse, and also sometimes in their actions (particularly by their decision to live in the 
Grand Duchy), although this desire remained imbued with ambivalence. We have called them "the ambivalents", since they were torn in this way between their various discursive positions and their acts, the latter not necessarily exactly reflecting the former. This means that there was an increased risk of cognitive dissonance; the ambivalents expressed their difficulties in positioning themselves not only in the social space but also in the territorial/geographical and even linguistic and cultural spaces. Let us now analyze the last group.

\section{The Greater Region as a reservoir of cultural resources}

We have placed in this group those respondents who, unlike the other groups, appeared to benefit from their particular geographical situation, considering the Greater Region to be a real reservoir of resources, mainly in cultural terms. The Greater Region may also be perceived as a resource for consumer goods, but this was extremely secondary in our survey. Thus, they differed from the previous two groups in their cultural practices, which were more substantial, and consequently in terms of the greater differentiation in their media practices, in as much as they were focused, in additional to general news, on seeking cultural information relating to the whole of the Greater Region.

\subsection{Occupying the territory of the Greater Region via cultural practices}

Cultural practices seemed to be the most discriminating dimension for characterizing this group: they chose to carry out their outside cultural activities (shows, music, lectures, etc.) throughout the Greater Region. A law of cumulation (Donnat 2007, 2009), well-known in the cultural field, operates here: these respondents were already describing more substantial and more frequent cultural practices than the other members of the sample, who mainly stayed close to home for their outside cultural activities. There may also be a "distinction" effect (Bourdieu 1979) in them seeking to occupy the territory to take advantage of all its resources. These respondents had understood the reality of the resources available in the Greater Region; the only condition was being mobile throughout the territory. Thus, they were not discouraged by the idea of traveling long distances after work, staying on in the evening, or coming back to the Grand Duchy at the weekend. Louis (a computer specialist, 25 years old) explained what the 
Greater Region meant to him: it is a roughly rectangular area (approximately 50 kilometers across and 100 kilometers from top to bottom), centered on Metz, and he was prepared to travel anywhere within it for all his outings. Mobility was also a feature for Charles, who realized, with his wife, what area was at his disposal:

And indeed we took a bit of time... [...] it's a... a mindset you need to have, it took us a while to say to ourselves... "We're just being stupid about this! It doesn't make any difference if it's in Luxembourg or Metz, there are loads of things going on".

Having decided to live in Thionville meant being aware of being halfway between Luxembourg and Metz, two culturally attractive cities which were considered and represented in a single mental universe and in a single territory; this virtually erased any ideas of borders and separation. But it also supposed a certain "mindset" since "you have to make the effort to get out of ... well, staying in a purely French environment". Charles went on to refer to "loads of things going on" in "the European capital", citing 'Hamlet' at the Grand Théatre and a concert by the philharmonic orchestra in Luxembourg City, at the Kulturfabrik, or even at the Rockhal (two concert venues in Esch-sur-Alzette); his wife (not a cross-border commuter) joins him after work: "we have something to eat and go back home after the show." The same was true of the other respondents in this group: it appears that their cultural practices were frequent and substantially above the average for our sample. Let us now look at their media practices.

\subsection{Additional media practices, turned toward looking for cultural information}

The media practices of members of this group with regard to general and political news were not basically any different from those of the other cross-border commuters. They read L'Essentiel, just like the others, but their discourse seemed to point toward greater openness and, above all, their media practices were very different, focusing on cultural news. Because in order to be able to engage in their cultural activities throughout the Greater Region, it was necessary for them to have full information on the shows, concerts, lectures, etc. taking place throughout the territory. And it was there that digital devices came to the fore, facilitating their active effort to seek specific topical information. Firstly, these cross-border commuters looking for cultural information used to subscribe to the various newsletters and alerts available from institutions organizing shows and/or the traditional media. This was explained by Louis, a subscriber to 
alerts from L'Essentiel.lu in order to obtain the information he needed to be able to travel throughout the Greater Region, which he referred to as his "action area", for his outings and leisure activities:

Well, for instance there I've got the news in the Grand Duchy [via L'Essentiel]; yesterday I got a number of alerts telling me "right, the Schueberfouer has started in the middle of Luxembourg"; it might be worth going. I've read a few articles about it, including some minor news items ... I saw there was going to be a presentation at the garden in Wiltz ... a bit of a special evening, very arty, with lanterns, on 10 September, I've penciled in the date already.

Secondly, some of the respondents in the group used social networks, particularly Twitter, which enabled them to forgo traditional media to some extent, and thus have access to cross-border information that was not systematically taken up in the traditional media.

The case of Charles was interesting: he had discovered Twitter three years earlier (he was an early adopter of it at the time of the survey) and he talked about the information consumption dimension, not without humor, explaining in great detail how it had taken some time but he had managed to get the hang of and finally make the most of using Twitter to carry out a real information watch for his Ph.D. thesis: the people on the list of his followers supplied information in the same way as a browser (Cardon 2010; Stenger/Coutant 2011). He subsequently decided to follow a number of institutional accounts circulating cultural information about the Greater Region, such as those of local authorities (Metz city, the Regional Council, the Council for the département) and a number of cultural institutions (the tourist board, the 'Pompidou Metz' Centre, concert halls in Lorraine and the Grand Duchy, including L'Atelier and the Rockhal). He ended by quoting the media on his list, including the France 3 and Mirabelle TV television channels-he was holding on to a few Tweets on cultural news topics-but his analysis was absolutely clear. It was indeed his use of Twitter which, by putting him in direct contact with the institutions and local authorities, etc. concerned, was enabling him to be almost certain of gathering all the available cultural information about the Greater Region, almost exhaustively because he had cumulated and crossed his sources of information. This new "way of operating" ("manière de faire") (de Certeau 2004) was combined with severe criticism of the traditional media regarding their inability to circulate cross-border information: 
I think it's because of the borders... er... I was going to say the geographical borders... artificial borders, rather... that are upheld by, er... I was going to say particularly by the traditional press, or even beyond that... that... information, or cultural information, at least yes, that's it, about cultural events that might be going on circulates, I'd say, with more difficulty and I think that by using the, the....well, everything that's new, the communication technologies... it's possible to get rid of all that!

The phrase was out- “it's possible to get rid of all that!" The criticism was clear and incisive - the traditional local and regional media (press, TV, radio) did not circulate information beyond national borders, particularly cultural information, and this new freedom (for that is what is at stake) had been won thanks to digital devices and social networks. This result was associated with a deep and more general criticism of the traditional media. Thus, for example, Louis mentioned the "lack of depth" to the information he was able to find in L'Essentiel, which was unsatisfactory for someone like him who was carrying out a specialized information watch. That was why he only read L'Essentiel occasionally and not systematically - "I've already got all the information options"; if there was an important event in the general news, he preferred to consult major media sites such as Le Monde for an in-depth critical analysis.

To conclude, we feel that this question of criticism of the media corresponds to an intensive use of Twitter. Quentin (a computer specialist, 26 years old) said nothing different when he explained how he decided whether or not to follow a person on Twitter:

It's the information they choose to share; you decide to follow them for that as well, because it's... the person, the idea, [...] you're not dependent on an editorial line any more, we've even managed to get rid of that.

What Quentin was looking for in the information he collected via Twitter (and in the information circulated by journalists) was the person's "own words" or "opinion"; he felt that carried more weight than if it was relayed by an "entity" or media institution. And he made the same strong demand for freedom expressed by Charles: "we've even managed to get rid of that [editorial line]." How should we understand Quentin's discourse? Our hypothesis is in line with the thoughts developed by Guillaume Caseaux (2014) on the individualization of information in the context of digital media practices. 


\section{Conclusion}

To sum up, a genuine digital border was identified on our completing this survey in 2012-2013: for more than twenty years, several tens of thousands of French (approximately 75,000) cross-border commuters were unable to use their mobile phones (for voice and data) as soon as they crossed the border every morning, unless they paid out-of-plan charges or equipped themselves with a second mobile phone. It has been possible to confirm our hypothesis by showing how this socio-technico-economic apparatus (roaming apparatus) may have configured the usage by and the practices of the cross-border commuters and de facto their daily border experiences. We witnessed some rather surprising examples of re-bordering, revealing discontinuities when the mobile phone was supposed to provide seamless communication. We have been able to construct a typology, dividing the cross-border commuters into three groups according to their media, cultural, and sociability practices, and their border experiences and social representations of that border.

The first group-the "tunnel effect" group-comprised those commuters who tended to reconstruct a border between their work and their private lives. In fact, the digital border fosters this divide between professional and private life and thus constructs their border experiences; their life in the area of the Grand-Duchy is linked to work and only to work. They developed virtually no social life in the Grand Duchy after work, apart from a few links with their commuter co-workers, and their cultural life was firmly rooted near their place of residence. Their media practices were thus centered on French and international news. Reading the L'Essentiel free newspaper was more than sufficient for them, providing them with a little local news about the Grand Duchy.

The second group-the "ambivalents"-comprised members of the independent professions who were mainly residents in the Grand Duchy. They were characterized by their ambivalence and paradoxes, expressing a real integration strategy. They were nevertheless "torn", as they had not broken their links with France, and some of them practiced a form of debordering, which meant that they did not have to make a choice between the two areas. Moreover, their ambivalence meant that they still often felt they were foreigners in the geographical area of the Grand Duchy, and their social, cultural, and media practices were ultimately not all that different from those of members of the first group, i.e. devoid of involvement in local life.

Lastly, the members of the third group perceived and experienced the Greater Region as a real reservoir of essentially cultural resources. Their 
cultural practices fell within a law of cumulation (Donnat 2007) and they had no hesitation in traveling anywhere in the territory for their outings after work or at the weekend. Their media practices differed from those of the other two groups mainly because they needed to look for cultural information. And we may say without fear of contradiction that this is fostered by digital devices and social networks, including Twitter, which made it much easier for them to find this cross-border information. Seeking information while bypassing the traditional media also led them to develop a critical discourse on the subject of the media; in the end, they were not unhappy to have managed to forgo it.

The results presented, on the basis of a qualitative sample of twenty people, however diversified it may be, cannot claim to be of any general value. They may, however, constitute areas for further thought, particularly as some of our respondents could be considered pioneers, at the time the survey was carried out, in their use of digital devices and social media. With this empirical survey, we tested the influence of the economico-technical apparatus of roaming on the digital media practices of cross-border commuters; it would be relevant to conduct an equivalent survey, to observe the impacts of the abolition of roaming charges since June 2017. Have the digital media practices of border residents increased since the end of the disconnection at the border? And in what way? With the network in France and/or also with the network of colleagues, particularly in the area of the Grand-Duchy? Has their experience of the border evolved towards broader forms of de-bordering, close to transnationalism, fostered by the Internet, digital media and social networks? We may hypothesize that it is more continuous and approaches seamless communication, which was the social imaginary of the ubiquity associated with the very first mobile communications.

\section{References}

Amilhat Szary, Anne-Laure (2016): La frontière au-delà des idées reçues. In: Revue internationale et stratégique 2, no. 102, p. 147-153.

Aubert, Nicole (2010): Le culte de l'urgence. La société malade du temps. Paris: Flammarion.

Belkacem, Rachid/Pigeron-Piroth, Isabelle (eds.) (2012): Le travail frontalier au sein de la Grande Région Saar-Lor-Lux. Pratiques, enjeux et perspectives. Nancy: Presses universitaires de Nancy.

Blanchet, Alain (1985): L'entretien dans les sciences sociales. L'écoute, la parole et le sens. Paris: Dunod. 
Blanchet, Alain/Gotman, Anne (1992): L'enquête et ses méthodes: l'entretien. Paris: Nathan.

Bolzman, Claudio/Gakuba Théogène-Octave/Minko Siboney (2016): Résidents inattendus: trajectoires, dilemmes et situations de vie des Africains et latino-américains âgés en Suisse francophone. In: Vie Sociale 4, no. 16, p. 79-90.

Cardon, Dominique (2010): La démocratie internet. Promesses et limites. Paris: Seuil.

Cazeaux, Guillaune (2014): Odyssée 2.0. La démocratie dans la civilisation numérique. Paris: A. Colin.

Certeau de, Michel (1998): L'invention du quotidien. Tome 1. Arts de faire. Paris: Gallimard.

Donnat, Olivier (2009): Les pratiques culturelles des Français à l'ère numérique. Enquête 2008. Paris: Ed La Découverte/Ministère de la culture et de la communication.

Donnat, Olivier (2007): Diversité culturelle et combat contre la loi du cumul. In: Revues Plurielles.org, no. 148, access: http://www.revues-plurielles.org/php/ index.php

Durand, François (2015): Theoretical Framework of the Cross-border Space Production - The case of the Eurometropolis Lille - Kortrijk - Tournai. In: Journal of Borderlands Studies, 30, no. 3, p. 309-328, DOI: 10.1080/08865655.2015.1066 701.

Granjon, Fabien/Le Foulgoc, Aurélien (2010): Les usages sociaux de l'actualité. In: Réseaux "Presse en ligne" 2, no. 160-161, p. 225-253.

Granjon, Fabien/Le Foulgoc, Aurélien (2011): Penser les usages sociaux de l'actualité. In: Réseaux "Actualités et citoyenneté à l'ère numérique” 6, no. 170, p. 1743.

Goulet, Vincent, Vatter/Christoph (eds.) (2013): Champs médiatiques et frontières dans la "Grande Région" SaarLorLux et en Europe. Mediale Felder und Grenzen in der Grossregion SaarLorLux und in Europa. Nancy: Presses universitaires de Nancy.

Goulet, Vincent/Vatter, Christoph (eds.) (2015): Grenzüberschreitende Informationsflüsse und Medien in der Großregion SaarLorLux. La circulation transfrontalière des informations médiatiques dans la Grande Région Saar-Lor-Lux. Baden-Baden: Nomos.

Hamez, Gregory (2015): Pour une analyse géographique des espaces transfrontaliers. Mémoire HDR, Université de Rouen.

Hamman, Philippe (2005): Les travailleurs frontaliers en Europe. Mobilités et mobilisations transnationales. Paris: L'Harmattan.

Jauréguiberry, Francis (2014): La déconnexion aux technologies de communication. In: Réseaux "La Déconnexion” 4, no. 186, p. 15-49.

Jouët, Josiane (2001): Retour critique sur la sociologie des usages, In: Réseaux 18, no. 100 , p. 487-521.

Jouët, Josiane/Rieffel, Rémy (eds.) (2013): S'informer à l'ère numérique. Rennes: Presses universitaires de Rennes. 
Kaufmann, Jean-Claude (1996): L’entretien compréhensif. Paris: Nathan.

Kaufmann, Vincent/Jemelin, Christophe (2008): La motilité, une forme de capital permettant d'éviter les irréversibilités socio-spatiales? In: Sechet, R./Garat, I./ Zeneidi, D. (eds.): Espaces en transaction. Rennes: Presses universitaires de Rennes, DOI : $10.4000 /$ books.pur.432.

Koukoutsaki-Monnier, Angeliki (ed.) (2014): Identités (trans)frontalières au sein et autour de l'espace du Rhin supérieur. Nancy: Presses universitaires de Nancy.

Lamour, Christian (2015): La presse gratuite comme vecteur d'une métropolisation transfrontalière? In: Goulet, V./Vatter, C. (eds.): Grenzüberschreitende Informationsflüsse und Medien in der Großregion SaarLorLux. La circulation transfrontalière des informations médiatiques dans la Grande Région Saar-Lor-Lux. Baden-Baden: Nomos, p. 79-103.

Martin, Corinne (2004): Représentations sociales du téléphone portable chez les jeunes adolescents et leur famille. Quelles légitimations des usages? Doctoral thesis, Sciences de l'information et de la communication, Université Paul Verlaine-Metz. http://docnum.univ-lorraine.fr/public/UPV-M/Theses/2004/Martin. Corinne.LMZ0413.pdf.

Moscovici, Serge (2005): L'âge des foules. Un traité historique de psychologie des masses. Paris: Fayard.

Pigeron-Piroth, Isabelle (2009): Le secteur public. In: Économie et statistiques 34, p. 1-34.

Silverstone, Roger/Haddon, Leslie (1996): Design and the domestication of information and communication technologies: technical change and everyday life. In: Mansell, R./Silverstone, R. (eds.): Communication by Design: The Politics of Information and Communication Technologies. Oxford: Oxford University Press, p. 44-74.

Stenger, Thomas/Coutant, Alexandre (eds.) (2011): Ces réseaux numériques dits sociaux. In: Hermès, no. 59.

\section{About the author}

Corinne Martin | University of Lorraine | Centre de Recherche sur les Médiations | Ile du Saulcy | F-57045 Metz Cedex 1 | France | T +33 684306612 | corinne.martin@univ-lorraine.fr

Corinne Martin is a sociopsychologist. She obtained her Ph.D. in Information and Communication Sciences in 2004, and is an Associate Professor at the University of Lorraine (France)/ Centre de Recherche sur les Médiations (CREM, ÉA 3476). She has worked on digital practices, mobile culture (mobile phones/smartphones), digital media, and social networks, and has extended her research to digital culture within different territories (e.g. third places). She is also participating in the "13-Novembre" program, a cross-disciplinary research program (2016-2028) on the construction and evolution of individual and collective memory after the terrorist attacks in Paris in 2015. 